\title{
Геохимические особенности измененных пород на месторождениях рудного поля Лобаш, Карелия
}

Кулешевич Л.В., Дмитриева А.В.

Институт геологии КарНЦ РАН, Петрозаводск, kuleshev@krc.karelia.ru;dmitrievaa-v@yandex.ru

\begin{abstract}
Аннотация. Молибденовое и золото-полиметаллическое месторождения рудного поля Лобаш приурочены к зеленокаменным толщам позднеархейского возраста, которые прорываются разновозрастными интрузиями габброидов, дайками дацитов-риодацитов и двухфазной гранодиорит-гранит-порфировой интрузией. На молибденовом месторождении Лобаш в ореоле не выходящей на поверхность гранит-порфировой интрузии формируются эпидозиты по габбро; пропилиты - по базальтам, андезитам; окварцевание и альбитизация развиваются по кислым породам (дайкам); биотитизация - по всем типам вмещающих оруденение пород. В минеральном и химическом составе ведущих типов метасоматитов (пропилитов и биотититов) наблюдаются контрастные изменения по $\mathrm{CaO}, \mathrm{K}_{2} \mathrm{O}$, редким щелочам и рудогенным элементам, сопровождающие метасоматические изменения вмещающих пород. В работе рассматриваются петро- и геохимические особенности разных типов вмещающих пород и их изменения, сопровождающие становление флюидно- рудномагматической системы Лобаш.
\end{abstract}

Ключевые слова: метасоматиты, геохимия, рудное поле Лобаш, Карелия.

\section{Geochemical characteristics of altered rocks at Lobash Ore Field deposits, Karelia}

Kuleshevich L.V., Dmitrieva A.V. Institute of Geology,KarRC,RAS,Petrozavodsk,kuleshev@krc.karelia.ru; dmitrievaa-v@yandex.ru

\begin{abstract}
The molybdenum and gold-base-metal deposits of the Lobash Ore Field are confined to Late Archean greenstone sequences cut by gabbroic rock intrusions, dacite-rhyodacite dikes and two-phase granodioritegranite-porphyry intrusion of various ages. Forming at the Lobash molybdenum deposit in the aureole of subsurface granite-porphyry intrusion are epidosites after gabbro such as propylites after basalts and andesites; silicification and albitization evolve after felsic rocks (dikes); biotitization occurs in all types of mineralization-hosting rocks. The mineral and chemical composition of major types of metasomatic rocks (propylites and biotittes) display contrasting alterations after $\mathrm{CaO}, \mathrm{K}_{2} \mathrm{O}$, rare alkalies and ore-bearing elements that accompany the metasomatic alterations of host rocks. The petro- and geochemical characteristics of various types of host rocks and their alterations that accompany the formation of the Lobash fluid-ore-magmatic system are discussed.
\end{abstract}

Key words: metasomatic rocks, geochemistry, Lobash Ore Field, Karelia.

\section{Введение}

Месторождение Лобаш - наиболее значительный молибденовый жильно-штокверковый рудный объект в позднеархейских зеленокаменных поясах Карелии, обладающий значительными ресурсами и запасами; Лобаш-1 - небольшое золото-полиметаллическое рудопроявление (Минерально..., 2005; Покалов, Семенова, 1993; Тытык, Фролов, 2014). Формирование Au-Cu-Moпорфирового оруденения связывается с внедрением двухфазной гранитной интрузии. Отложение молибденового оруденения происходит в эндо- и преимущественно экзоконтактовой зоне второй фазы массива Лобаш и сопровождается интенсивными изменениями пород. Целью данной работы было показать петро- и геохимические особенности формирующейся флюидо-магматической системы - метасоматические изменения вмещающих толщ на разных стадиях процесса.

\section{Фактический материал и методы}

Состав вмещающих и интрузивных пород и их метасоматические изменения, сопровождающие внедрение гранитоидов и формирование оруденения, изучались по образцам, отобранным из скважин и обнажений рудного поля Лобаш. Характер изменений пород определялся в процессе полевого наблюдения при отборе образцов и оптическим методом при просмотре большого количе- 
ства шлифов. Состав пород анализировался традиционным химическим методом силикатного анализа, дополнительно определялись некоторые отдельные компоненты. Микрокомпонентный состав неизмененных пород и метасоматитов определялись с использованием ICP-MS-анализа (на квадрупольном масс-спектрометре XSeries 2 ICP-MS, Thermo Scientific, США) в аналитическом центре ИГ КарНЦ РАН (г. Петрозаводск) по существующей методике прибора.

\section{Результаты исследований: геологическое строение и типы рудной минерализации}

Геологическое строение рудного поля Лобаш освещено в ряде отчетов по проводимым здесь поисково-оценочным работам на молибден, медь и благородные металлы (С.Н. Юдина, Г.Н. Пироженко, В.М. Тытыка за 1985-1998 года), а также в статьях (Кулешевич, 2000; Иваников, 1995; Тытык, Фролов, 2014). Вмещающие вулканогенно-осадочные толщи представлены метабазальтами, андезитами и сланцами по туфам среднего и кислого состава, относимые к пебозерской серии (с возрастом $2801.6 \pm 3.6$ млн. лет). Они прорываются интрузивными телами габброидов, дайками риодацитов и двухфазным гранитоидным массивом. Массив представлен гранодиоритами 1-й фазы и порфировидными гранитами и лейкогранитами 2-й фазы, имеющими U-Pb возраст 2720-2715 млн. лет (Богачев и др., 2009; 2013). Не выходящие на поверхность граниты 2-й фазы относятся к рудопродуцирующим: Лобашская интрузия подсечена бурением на глубине 100-150 м и прослежена на 2.5 км. С гранитами связана молибденовая рудная минерализация, возраст которой по данным Re/Os-датирования молибденита близок становлению гранитов и равен 2715-2722 млн. лет (Богачев и др., 2013).

Рудный штокверк молибденового месторождения Лобаш находится в апикальной части интрузии. Он приурочен к кровле погруженного массива, конформен ей, имеет ССВ простирание и прослеживается от южной до центральной части рудного поля (Тытык, Фролов, 2014). Молибденитовое оруденение представлено: 1 - богатой гнездово-вкрапленной минерализацией в кварцевой жиле, в гранитах; и 2 - вкрапленно-прожилковой в эпидотизированных и биотитизированных вмещающих толщах и секущих их габброидах. Золото-полиметаллическая минерализация месторождения Лобаш-1 установлена несколько севернее молибденового месторождения, она приурочена к зонам рассланцевания и биотитизации на контактах даек кварц-плагиопорфиров (дацитовриодацитов) и во вмещающих толщах - туфах среднего состава и измененных габброидах (Кулешевич и др., 2004; Тытык, Фролов 2014).

\section{Состав вмещающих пород и секущих их гранитоидов}

Вмещающие толщи в южной части рудного поля (на Лобаше молибденовом) представлены туфами андезитов, базальтами и прорывающими их габброидами. Вмещающие толщи и тело габброидов секутся дайками дацитов-риодацитов. В северной части (на золото-полиметаллическом месторождении Лобаш-1) вмещающие толщи представлены средними и кислыми толщами - андезитами и их туфами (агломератовыми и слоистыми), риодацитами. Они также прорываются габброидами и дайками кислого состава. Внедрившиеся гранитоиды представлены массивом, дифференцированным от гранодиоритов до гранит-порфиров и лейкократовых гранитов. Химические составы вмещающих пород и гранитов представлены в таблице 1 и обобщенно вынесены на рисунок 1.

Вмещающие толщи и габбро секутся массивом гранодиоритов 1 фазы (обнажаются на восточном берегу озера). Биотитовые гранодиориты - серые средне- и крупнозернистые породы, содержат ксенолиты всещающих андезитов и базальтов. Гранодиориты состоят из плагиоклаза (60 \%), кварца (20-25 \%), микроклина (5-10\%), биотита (5\%), содержат амфибол (2\%), эпидот (1 \%) и акцессорные - сфен, апатит, циркон, реже ортит. Гранодиориты содержат $\mathrm{SiO}_{2}-66.81 \%, \mathrm{Al}_{2} \mathrm{O}_{3}-14.77$ \%, относятся к известково-щелочным, имеют $\mathrm{K}-\mathrm{Na}$ щелочность, сумму щелочей 7.0 \% и повышенную глиноземистость.

Граниты 2 фазы образуют небольшое тело в краевой части массива, вскрытое на глубине. Это розовато-серые неравномерно зернистые породы, содержащие плагиоклаз (30-50 \%), микроклин (20-40 \%), кварц (25-30 \%), биотит (1-5\%), мусковит (1 \%), реже эпидот, хлорит, акцессорные ортит, сфен, апатит, циркон. В краевой части породы имеют порфировый облик. Содержание $\mathrm{SiO}_{2}$ в гранитах составляет $74.29 \%, \mathrm{Al}_{2} \mathrm{O}_{3}-12.86 \%, \mathrm{Na}_{2} \mathrm{O}-3.70 \%, \mathrm{~K}_{2} \mathrm{O}-4.72 \%$, сумма щелочей $-8.42 \%$. 

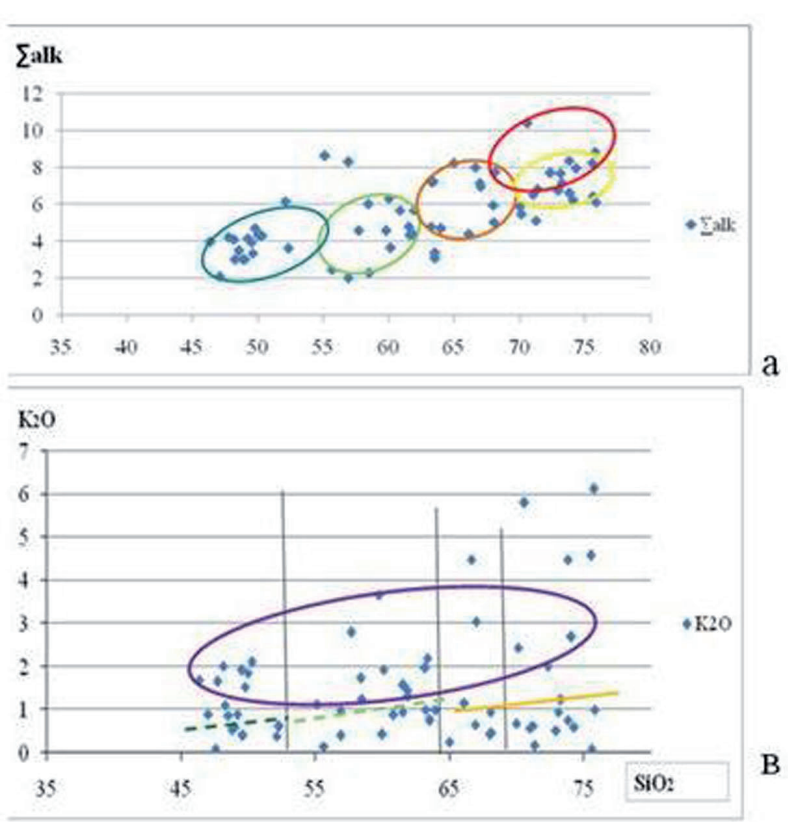

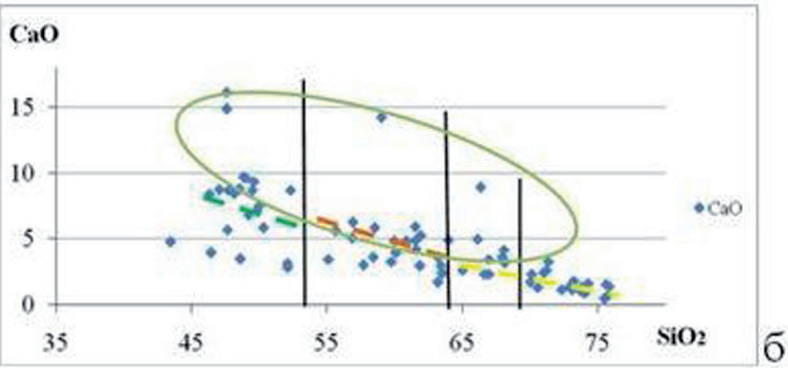

Рис. 1. Изменения пород (по основным петрогенным компонентам) рудного поля Лобаш: $\mathrm{a}-\mathrm{SiO}_{2}-\left(\mathrm{Na}_{2} \mathrm{O}+\mathrm{K}_{2} \mathrm{O}\right), \sigma-\mathrm{SiO}_{2}-\mathrm{CaO}$, в $-\mathrm{SiO}_{2}-\mathrm{K}_{2} \mathrm{O}$.

Fig. 1. Rock alteration pattern (for major petrogenic components) of the Lobash Ore Field.: $\mathrm{a}-\mathrm{SiO}_{2}-\left(\mathrm{Na}_{2} \mathrm{O}+\mathrm{K}_{2} \mathrm{O}\right)$, б $-\mathrm{SiO}_{2}-\mathrm{CaO}$, в $-\mathrm{SiO}_{2}-\mathrm{K}_{2} \mathrm{O}$.

Лейкограниты представляют собой мелкозернистые светло-розовые граниты, развитые в прикровельной части и апофизах, секущих вмещающие толщи и гранодиориты. В них количество микроклина достигает 40-60 \%, альбита 30-40 \%, кварца $20 \%$, мусковита 5-7 \%, биотита 1-2 \%. Среднее содержание $\mathrm{SiO}_{2}$ в них $69.54 \%, \mathrm{~K}_{2} \mathrm{O}-7.65 \%, \mathrm{Na}_{2} \mathrm{O}-3.96 \%$, сумма щелочей $-11.61 \%, \mathrm{Rb}_{2} \mathrm{O}$ - до $0.046 \%$, относятся к субщелочным, но скорее изменены под влиянием флюидов.

В эндоконтактовой зоне непосредственно Лобашской интрузии (до 10 м от контакта) граниты представлены плагиогранит-порфирами. На глубину (20-80 м от кровли) они постепенно сменяются гранит-порфирами сначала с мелкозернистой затем - со средне-крупнозернистой основной массой и вкрапленниками калиевого полевого шпата, затем постепенно переходят в порфировидные граниты (с вкрапленниками микроклина в количестве до 25 \%) - наиболее типичные представители пород массива. Основная масса гранитов состоит из олигоклаза, микроклина и кварца примерно в равных соотношениях. Темноцветные минералы представлены биотитом (3-5 \%); вторичные минералы: мусковит (3-5 \%, до 20 \% в зонах изменения), альбит, хлорит, эпидот, карбонат, флюорит. Акцессорные минералы - апатит, титанит, циркон, реже алланит.

Гранитоиды-1 относятся к пер- и метаалюминевым породам и на петрохимических диаграммах обособляются в области синколлизионных пород. Граниты-2 и лейкограниты попадают в область анорогенных пород. Они содержат кварцевые жилы и рудную молибденитовую рудную минерализацию (молибденит, пирит, халькопирит).

\section{Гидротермально-метасоматические изменения пород}

Постмагматические гидротермально-метасоматические процессы в ореоле гранитного массива интенсивно изменили весь комплекс вмещающих пород. Максимальные изменения вмещающих толщ проявлены над апикальной областью, не выходящей на поверхность интрузии. Грейзенизация и окварцевание наиболее характерны для изменений в апикальной части гранитов как 1-й так и 2-й фаз, эпидотизация и биотитизация развиты во вмещающих толщах, где наиболее широко распространены породы андезитового состава и габбро. Химический состав наиболее типичных метасоматитов в сравнении с составами первичных пород приведен в (табл. 1).

Гранодиориты-1 в эндоконтактовой зоне березитизированы, в них появляются серицит, кварц-2, карбонат, пирит. Для изменений в апикальной части гранитов 2-й фазы наиболее характерны грейзенизация и окварцевание. Грейзенизированные гранит-порфиры представлены кварцем, мусковитом (иногда до 20 \%). В них встречаются альбит, хлорит, эпидот, карбонат, флюорит, пирит, молибденит. Измененные граниты секутся крупными кварцевыми жилами с молибденитом и пиритом. 


\begin{tabular}{|c|c|c|c|c|c|c|c|c|c|c|c|c|c|c|c|c|c|c|c|c|c|c|c|c|}
\hline & $\tilde{\sim}$ & $\begin{array}{l}\text { İ } \\
\stackrel{i}{r}\end{array}$ & $\frac{n}{0}$ & $\stackrel{\grave{N}}{ \pm}$ & $\frac{\pi}{n}$ & $\vec{\sim}$ & de & $\frac{2}{0}$ & $\vec{m}$ & $\begin{array}{l}0 \\
\dot{r}\end{array}$ & $\stackrel{?}{=}$ & $\stackrel{8}{\circ}$ & $\stackrel{\infty}{\infty}$ & $\overrightarrow{8}$ & 6 & $\begin{array}{l}n \\
\tilde{o} \\
\vdots \\
0\end{array}$ & 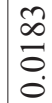 & ồ & 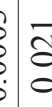 & $\stackrel{0}{0}$ & - & & 8 & 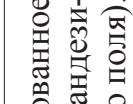 \\
\hline & $\vec{\sim}$ & $\underset{i}{i}$ & $\frac{\infty}{0}$ & $\stackrel{9}{2}$ & ñ & $\stackrel{6}{-}$ & ô. & $\left\{\begin{array}{l}\infty \\
\infty \\
0 \\
0\end{array}\right.$ & iิ & is & 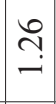 & 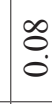 & @. & $\frac{2}{2}$ & $=$ & 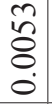 & oे & 告 & & & $\infty$ & & $\begin{array}{l}2 \\
6 \\
6\end{array}$ & 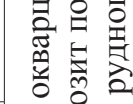 \\
\hline \multirow{21}{*}{ 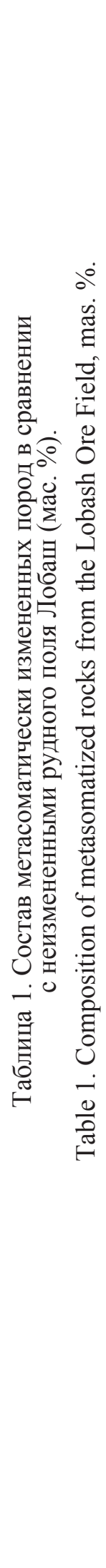 } & స & 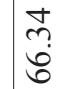 & $\stackrel{\infty}{+}$ & $\stackrel{\text { f }}{\Xi}$ & $\begin{array}{l}m \\
\infty \\
n\end{array}$ & $\stackrel{n}{n}$ & $\frac{\pi}{0}$ & $\begin{array}{l}\infty \\
\infty \\
0\end{array}$ & $\hat{\infty}$ & $\stackrel{m}{\tilde{\sigma}}$ & సे & & 守 & $\ddot{2}$ & - & & & & & & - & & a & 으 志志 \\
\hline & $\stackrel{\varrho}{ }$ & $\frac{n}{n}$ & $\stackrel{0}{8}$ & à & तै & $\stackrel{m}{=}$ & 离 & $\stackrel{0}{=}$ & ते & فे & ?̊n & $\stackrel{0}{0}$ & ले & $\begin{array}{l}\infty \\
2 \\
2\end{array}$ & N & 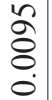 & $\begin{array}{l}\tilde{O} \\
0 \\
0 \\
0 \\
0\end{array}$ & ồ & $\begin{array}{l}0 \\
\vdots \\
\vdots \\
\vdots\end{array}$ & $\begin{array}{l}5 \\
0 \\
0 \\
0\end{array}$ & - & & $\begin{array}{l}1 \\
1 \\
0\end{array}$ & $\begin{array}{l}8 \\
0\end{array}$ \\
\hline & $\stackrel{\infty}{\stackrel{\infty}{2}}$ & $\begin{array}{l}2 \\
2 \\
i\end{array}$ & $\begin{array}{l}\infty \\
\infty \\
0\end{array}$ & $\begin{array}{l}m \\
\infty \\
\infty\end{array}$ & $\stackrel{\infty}{\stackrel{\infty}{\sim}}$ & $\stackrel{\odot}{\circ}$ & $\begin{array}{l}\infty \\
0 \\
0 \\
0\end{array}$ & $\stackrel{5}{0}$ & $\stackrel{n}{n}$ & $\hat{\sigma}$ & $\begin{array}{l}8 \\
\dot{0} \\
\dot{r}\end{array}$ & $\stackrel{J}{0}$ & $\underset{\dot{q}}{\stackrel{q}{r}}$ & बें & - & & & & & & - & & in & \\
\hline & $=$ & $\begin{array}{l}6 \\
i \\
i\end{array}$ & $\frac{0}{2}$ & $\stackrel{n}{0}$ & 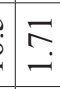 & $\stackrel{2}{r}$ & $\stackrel{\infty}{0}$ & $=$ & बे & $\stackrel{\infty}{-}$ & $\frac{2}{i}$ & & & $\begin{array}{l}\infty \\
2 \\
\alpha\end{array}$ & - & & & & & & - & & in & \\
\hline & 0 & $\begin{array}{l}0 \\
0 \\
\text { in }\end{array}$ & : & $\begin{array}{l}\infty \\
\infty \\
\end{array}$ & $\stackrel{\infty}{i}$ & $\stackrel{?}{=}$ & $\stackrel{\infty}{m}$ & $\tilde{n}$ & $\overrightarrow{\tilde{I}}$ & $\begin{array}{l}\tilde{b} \\
0 \\
0\end{array}$ & $\begin{array}{l}\tilde{0} \\
0 \\
0\end{array}$ & $\stackrel{m}{0}$ & $\stackrel{\overbrace{}}{乛}$ & $\begin{array}{l}\infty \\
2\end{array}$ & - & & & & & & - & & 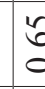 & 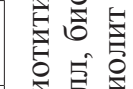 \\
\hline & $\stackrel{n}{\sim}$ & $\begin{array}{l}8 \\
8 \\
8\end{array}$ & 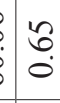 & $\stackrel{n}{i}$ & $\stackrel{\overbrace{}}{-}$ & $\begin{array}{l}n \\
n \\
n\end{array}$ & $\stackrel{1}{\circ}$ & $\tilde{r}$ & $\underset{+}{\stackrel{f}{+}}$ & $\begin{array}{l}\infty \\
\infty \\
\infty\end{array}$ & $\begin{array}{l}0 \\
\infty \\
- \\
-\end{array}$ & กิ & $\stackrel{n}{n}$ & $\stackrel{2}{2}$ & N & $\begin{array}{l}\vec{t} \\
\vec{\delta} \\
\dot{0}\end{array}$ & ڤ̊ & $\stackrel{m}{8}$ & : & $\int_{0}^{\infty}$ & ? & & $\begin{array}{l}\text { in } \\
\text { in }\end{array}$ & \\
\hline & $\Xi$ & $\frac{n}{6}$ & $\stackrel{0}{\circ}$ & $\begin{array}{l}\partial \\
\stackrel{2}{2}\end{array}$ & $\underset{-}{+}$ & 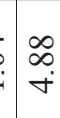 & $:$ & $\stackrel{?}{+}$ & $\stackrel{m}{m}$ & $\dot{m}$ & $\stackrel{\overrightarrow{0}}{-}$ & $\frac{\infty}{0}$ & $\stackrel{n}{n}$ & $\begin{array}{l}\bar{\infty} \\
\dot{\alpha}\end{array}$ & $\simeq$ & $\begin{array}{l}\exists \\
\\
0 \\
0\end{array}$ & $\frac{\tilde{m}}{\tilde{O}} \stackrel{0}{0}$ & : & $\begin{array}{l}b \\
b \\
b \\
b \\
b\end{array}$ & $\begin{array}{l}\Delta \\
\dot{0}\end{array}$ & $\infty$ & & $\bar{\gamma}$ & \\
\hline & 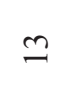 & $\begin{array}{l}f \\
f \\
\infty \\
i n\end{array}$ & F & $\begin{array}{l}n \\
n \\
n\end{array}$ & $\stackrel{\infty}{\infty}$ & $\frac{0}{m}$ & $=$ & $\stackrel{\infty}{i}$ & in & $\hat{\sigma}$ & $\vec{\sigma}$ & $\stackrel{1}{0}$ & $\frac{\infty}{\vec{i}}$ & $\frac{\infty}{a}$ & $\mathrm{~N}$ & हิे & $\begin{array}{l}n \\
8 \\
0\end{array}$ & ô & $\vec{b}$ & 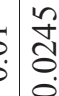 & : & & 9 & \\
\hline & $\simeq$ & $\begin{array}{l}\dot{f} \\
\dot{q}\end{array}$ & $\frac{\text { t }}{\stackrel{0}{0}}$ & $\begin{array}{l}\infty \\
\dot{I}\end{array}$ & 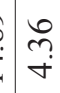 & {$\left[\begin{array}{l}\infty \\
\propto \\
\sigma\end{array}\right.$} & $\overline{0}$ & $\prod_{\infty}^{+}$ & m & m. & $\begin{array}{l}l \\
\stackrel{0}{+} \\
+\end{array}$ & $\stackrel{7}{0}$ & $\begin{array}{l}\hat{\sigma} \\
\dot{n}\end{array}$ & $\begin{array}{l}\hat{n} \\
2 \\
2\end{array}$ & $\mathrm{~m}$ & & & & & & $m$ & 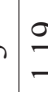 & ஓ & \\
\hline & $=$ & $\begin{array}{l}\hat{n} \\
\tilde{n}\end{array}$ & $\stackrel{?}{\stackrel{0}{0}}$ & $\begin{array}{l}\stackrel{n}{n} \\
\stackrel{n}{n}\end{array}$ & $\stackrel{?}{\imath}$ & $\stackrel{\infty}{\stackrel{\infty}{r}}$ & $\frac{\nabla}{0}$ & 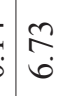 & 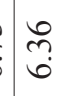 & $\stackrel{\tilde{i}}{i}$ & $\begin{array}{l}\hat{6} \\
0 \\
0\end{array}$ & กั & $\begin{array}{l}\bar{\sigma} \\
\dot{n}\end{array}$ & $\begin{array}{l}n \\
n \\
\alpha \\
\alpha\end{array}$ & 6 & \begin{tabular}{|l}
$\infty$ \\
0 \\
0 \\
0 \\
0
\end{tabular} & $\begin{array}{l}0 \\
2 \\
0 \\
0 \\
0\end{array}$ & : & & & n & & ר & \\
\hline & 으 & $\frac{n}{6}$ & సે & {$\left[\begin{array}{l}\infty \\
0 \\
\varrho\end{array}\right.$} & तु & $\stackrel{\hat{m}}{m}$ & $\frac{0}{ \pm}$ & $\stackrel{m}{m}$ & $\begin{array}{l}\infty \\
\infty \\
i\end{array}$ & $\begin{array}{l}\infty \\
\stackrel{n}{i}\end{array}$ & f̊ & $\stackrel{\Im}{\exists}$ & $\stackrel{\circ}{+}$ & $\frac{m}{\stackrel{\alpha}{\sigma}}$ & - & $\mid \begin{array}{l}0 \\
0 \\
0 \\
0 \\
0\end{array}$ & \&े & $\stackrel{1}{8}$ & & & - & $\stackrel{\alpha}{\sigma}$ & 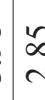 & \\
\hline & $a$ & $\begin{array}{l}\tilde{f} \\
\dot{f} \\
\text { f }\end{array}$ & 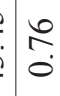 & $\stackrel{\sim}{\underset{ \pm}{ \pm}}$ & Oे & $\stackrel{\infty}{\stackrel{\infty}{=}}$ & $\frac{n}{0}$ & $\underset{\infty}{\stackrel{\infty}{\infty}}$ & $\stackrel{F}{F}$ & $\exists$ & $\ddot{r}$ & $\stackrel{2}{0}$ & $\underset{\sim}{\sigma}$ & $\bar{\alpha}$ & - & & & & & & - & c & $\ddot{z}$ & \\
\hline & $\infty$ & $\begin{array}{l}\text { ț } \\
\stackrel{f}{\sigma}\end{array}$ & $\stackrel{?}{\simeq}$ & 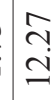 & $\stackrel{m}{\Rightarrow}$ & $\exists$ & 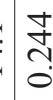 & $\stackrel{\vec{\sigma}}{\overrightarrow{+}}$ & $\begin{array}{l}5 \\
i \\
i\end{array}$ & o. & $\stackrel{F}{\dot{\sigma}}$ & $\frac{\infty}{0}$ & $\underset{\forall}{\stackrel{\nabla}{*}}$ & $\begin{array}{l}\vec{\gamma} \\
\dot{\alpha}\end{array}$ & - & 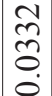 & \begin{tabular}{l}
\multirow{J}{J}{} \\
$\infty$ \\
0 \\
0
\end{tabular} & \&. & & & - & & an & \\
\hline & $r$ & $\begin{array}{l}\stackrel{0}{\dot{\gamma}} \\
\dot{\gamma}\end{array}$ & $\because$ & $\begin{array}{l}\tilde{J} \\
\dot{I}\end{array}$ & 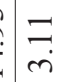 & $\frac{n}{n}$ & స్ & 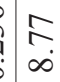 & $\frac{7}{6}$ & กิ & Ö & & $\stackrel{m}{r}$ & $\begin{array}{l}\text { t } \\
\text { वें }\end{array}$ & - & & & & & & - & & తీ & \\
\hline & 0 & $\begin{array}{l}\infty \\
\stackrel{\sim}{\sim} \\
\sim\end{array}$ & $\cong$ & $\mid \begin{array}{l}\mathfrak{n} \\
\dot{ \pm}\end{array}$ & $\stackrel{\overbrace{}}{\stackrel{f}{r}}$ & $=\frac{I}{i n}$ & \begin{tabular}{l}
0 \\
\multirow{2}{0}{}
\end{tabular} & in & $\begin{array}{l} \pm \\
\dot{I}\end{array}$ & $\begin{array}{l}0 \\
\text { ñ } \\
0\end{array}$ & $\ddot{0}$ & $\stackrel{\infty}{\circ}$ & $\begin{array}{l}\infty \\
\sim \\
\sim\end{array}$ & $\begin{array}{l}\hat{\sigma} \\
\alpha \\
\alpha\end{array}$ & - & $\begin{array}{l}1 \\
8 \\
0 \\
0\end{array}$ & $\begin{array}{l}0 \\
\vdots \\
0 \\
0\end{array}$ & 8 & & & - & $\stackrel{\alpha}{c}$ & 5 & \\
\hline & in & $\vec{n} \underset{\dot{q}}{ }$ & $\hat{o}$ & $\begin{array}{l}\stackrel{f}{\sim} \\
\stackrel{\sim}{\sim}\end{array}$ & 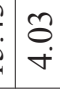 & $=$ & $\vec{\sim}$ & $\begin{array}{l}\stackrel{b}{0} \\
\stackrel{0}{0}\end{array}$ & $\stackrel{\infty}{\infty}$ & $\stackrel{i}{i}$ & 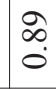 & $\stackrel{1}{\circ}$ & 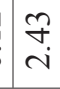 & $\begin{array}{l}\hat{\infty} \\
\alpha \\
\alpha\end{array}$ & $\cong$ & $\begin{array}{l}0 \\
\dot{8} \\
0 \\
0\end{array}$ & 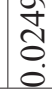 & 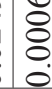 & & & $m$ & & 5 & \\
\hline & $\forall$ & 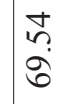 & $\stackrel{8}{\circ}$ & $\begin{array}{l}\approx \\
\sim \\
\sim\end{array}$ & $\underset{\circlearrowright}{F}$ & $\stackrel{\sigma}{\sigma}$ & $\stackrel{\delta}{\delta}$ & $\stackrel{?}{0}$ & d̆ & $\begin{array}{l}\stackrel{2}{2} \\
\text { r. }\end{array}$ & $\begin{array}{l}n \\
i \\
i\end{array}$ & $\stackrel{\sigma}{0}$ & 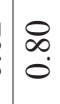 & $\begin{array}{l}\bar{\infty} \\
\alpha \\
\alpha\end{array}$ & $\sim$ & 䇂 & $\begin{array}{l}\infty \\
\text { on } \\
0 \\
0 \\
0\end{array}$ & & $\begin{array}{l}b \\
\vdots \\
\vdots \\
o\end{array}$ & $\stackrel{0}{0}$ & : & & 5 & \\
\hline & $m$ & $\begin{array}{l}\text { ָे } \\
\stackrel{ர}{\sim}\end{array}$ & $\stackrel{8}{0}$ & $\begin{array}{l}\curvearrowright \\
\stackrel{0}{\beth}\end{array}$ & $\stackrel{0}{0}$ & . & $\stackrel{t}{\circ}$ & $\underset{\Xi}{\vec{\sigma}}$ & $\stackrel{n}{\stackrel{2}{0}}$ & $\hat{m}$ & $\stackrel{\mathbb{T}}{\dot{r}}$ & $\hat{\sigma}$ & $\begin{array}{l}\infty \\
\infty \\
0\end{array}$ & $\begin{array}{l}\stackrel{\hat{\sigma}}{\Omega} \\
\stackrel{\alpha}{2}\end{array}$ & in & $\begin{array}{l}\infty \\
\tilde{\delta} \\
0 \\
0\end{array}$ & $\begin{array}{l}n \\
\tilde{n} \\
\hat{\sigma} \\
0\end{array}$ & 要 & $\begin{array}{l}b \\
b \\
b \\
b \\
\vdots \\
0\end{array}$ & $\stackrel{0}{0}$ & in & & f & \\
\hline & $N$ & $\begin{array}{l}\bar{\infty} \\
\dot{\delta}\end{array}$ & $\stackrel{n}{0}$ & $\stackrel{尺}{\stackrel{尺}{ \pm}}$ & $\hat{\sigma}$ & $\stackrel{n}{\sim}$ & $\stackrel{\infty}{\circ}$ & $\stackrel{\forall}{-}$ & $\overline{\widetilde{n}}$ & $\stackrel{m}{m}$ & $\begin{array}{l}\text { ஸे } \\
\text { ñ }\end{array}$ & $\stackrel{\circ}{\circ}$ & $\underset{i}{\stackrel{\infty}{i}}$ & $\begin{array}{l}\tilde{\alpha} \\
\alpha \\
\alpha\end{array}$ & N & $\begin{array}{l}0 \\
0 \\
0 \\
0\end{array}$ & 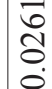 & 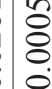 & $\begin{array}{l}b_{0}^{0} \\
\dot{b}\end{array}$ & 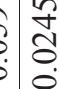 & 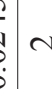 & & & \\
\hline & - & $\begin{array}{l}\sigma \\
\overrightarrow{6} \\
0\end{array}$ & 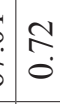 & $\widehat{\Im}$ & $\stackrel{\infty}{-}$ & $\stackrel{?}{\tau}$ & ڤ̊. & خे & $\stackrel{2}{\sim}$ & 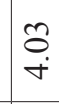 & $\begin{array}{l}\text { के } \\
\text { ○े }\end{array}$ & $\stackrel{\overbrace{}}{\circ}$ & $\begin{array}{l}\hat{b} \\
\stackrel{i}{1}\end{array}$ & $\begin{array}{l}\text { to. } \\
\dot{8} \\
0\end{array}$ & $r$ & \begin{tabular}{l}
$\infty$ \\
\multirow{8}{0}{} \\
0 \\
0
\end{tabular} & $\begin{array}{l}n \\
0 \\
0 \\
0\end{array}$ & : & $\begin{array}{l}n \\
\vdots \\
0 \\
3\end{array}$ & $\hat{\delta}$ & in & & & $-\therefore$ \\
\hline & 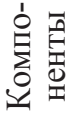 & ô & & & {$\left[\begin{array}{l}0 \\
0 \\
0 \\
1\end{array}\right.$} & & & 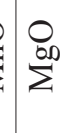 & & $\begin{array}{l}0 \\
\tilde{Z}^{\circ}\end{array}$ & $\underline{v}$ & ó & 見 & 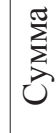 & & $\stackrel{0}{9}$ & $\simeq$ & & & $\tilde{\omega}$ & & $F$ & 7 & \\
\hline
\end{tabular}


В метабазальтах, габбро, андезитах и вмещающих сланцах по туфам среднего состава сначала развивается эпидотизация (пропилитизация), затем биотитизация. В габбро в экзоконтактовой зоне интрузии наиболее широкое развитие получают эпидозиты и эпидот-кварцевые прожилки, сопровождаемые мелкочешуйчатым молибденитом, пиритом, халькопиритом, пирротином, реже более поздними висмутотеллуритами. Интенсивная биотитизация отмечается по зонкам рассланцевания в андезитах и их туфах, а также на контактах даек дацитов-риодацитов. Биотитизация непосредственно фиксирует предрудный метасоматоз и позволяет выделять контур наиболее проработанных пород. Формирование почти мономинеральных биотититов по вмещающим породам среднего и основного состава сопоставляется с грейзенизацией кислых пород. Химический состав измененных пород вмещающих пород (табл. 1) по основным элементам представлен на рисунке 1.

\section{Заключение}

Несмотря на ряд протерозойских датировок биотититов, определенных $\mathrm{Rb}-\mathrm{Sr}$-методом (Кулешевич, 2004), очевидно что Лобашское месторождение молибдена и гранитная интрузия представляют собой единую рудно-магматическую систему с возрастом 2722-2715 млн. лет (U-Pb,

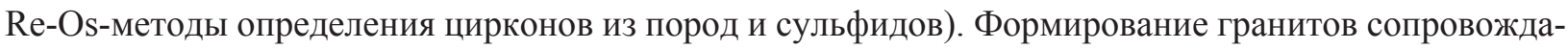
лось привносом гранитофильных элементов ( $\mathrm{K}$, редких щелочей, $\mathrm{Mo}, \mathrm{Pb}, \mathrm{Bi})$. Изменения вмещающих толщ на ранней стадии сопровождались образованием пропилитов-эпидозитов, на поздней - интенсивной биотитизацией. В геохимическом ореоле (по основным петрогенным элементам) сначала накоплением Са и Al-компонентов, затем K и редких щелочей. Грейзенизация формировались в апикальной части интрузии и вокруг крупной кварцевожильной зоны, а также в ореоле прожилков, слагающих штокверк и в зонках рассланцованных. В породах основного и среднего состава она проявлена как биотитизация. Биотитизация вмещающих толщ в пределах рудного поля является отчетливым поисковым признаком оруденения, связанного с гранитоидами.

\section{Литература}

1. Богачёв В.А. Иваников В.В., Крымский Р.Ш., Иващенко В.И., Беляцкий Б.В., Гольцин Н.А., Сергеева Э.И., Сергеев C.A. Изохронный Re-Os возраст молибденитов раннедокембрийских порфировых месторождений Карелии // Вестник С.-Петерб. университета. Сер. 7. 2013. Вып. 2. С. 3-20 .

2. Богачёв B.A., Иваников В.В., Сергеев C.A. U-Pb SHRIMP-датирование рудоносных гранитов Лобашского молибденового месторождения (Северо-Восточная Карелия) // Материалы Всероссийской конференции (Петрозаводск, 11-13 ноября 2009). 2009. С. $22-25$.

3. Иваников В.В., Богачев В.А., Левченков О.А. Архейский U-Pb цирконовый возраст рудоносной гранитной интрузии на молибденовом месторождении Лобаш (Карелия) // Вестник С.-Петерб. университета. Сер. 7. 2000. Вып. 3. № 32. С. 60-64.

4. Покалов В.Т., Семенова Н.В. Лобаш - первое крупное молибденовое месторождение докембрийского возраста (Карелия) // Геология рудных месторождений. 1993. № 3. С. 262-270.

5. Кулешевич Л.В., Тытык В.М., Коротаева Н.Н. Минералогия руд и околорудно-измененных пород золото-полиметаллического месторождкения Лобаш-1 (Карелия) // Записки РМО. 2004. № 4. С. 39-51.

6. Минерально-сырьевая база Р. Карелия. Петрозаводск. Изд-во: Карелия. 2005. 278 с.

7. Тытык В.М., Фролов П.В. Молибденовое месторождение Лобаш - крупный перспективный объект в Республике Карелия // Труды КарНЦ РАН. 2014. № 1. С. 56-62. 